\title{
Composition of the domestic water supply and the incidence of fractures and encephalopathy in patients on home dialysis
}

\author{
M M PLATTS, G C GOODE, J S HISLOP
}

British Medical fournal, 1977, 2, 657-660

\section{Summary}

Of the 202 patients undergoing home dialysis in the Trent region, 11 developed dialysis encephalopathy, 21 suffered spontaneous fractures, and 36 who had undergone dialysis for over four years had neither of these complications. Because the incidence of complications seemed to be unevenly distributed the water supplies were analysed. Water supplied to the homes of the patients with fractures or encephalopathy contained significantly less calcium and fluorine and significantly more aluminium and manganese than that piped to patients without these complications. The high aluminium concentrations in the bone of patients with encephalopathy was confirmed, but aluminium concentrations in the brains from three patients with encephalopathy were not increased.

Patients who undergo dialysis in areas where water contains high aluminium concentrations should be supplied with deionisers.

\section{Introduction}

Recent studies have suggested that dialysis encephalopathy may be a form of aluminium intoxication caused by ingesting

\section{Lodge Moor Hospital, Sheffield}

M M PLATTS, MD, FRCP, consultant nephrologist

Atomic Weapons Research Establishment, Aldermaston G C GOODE, BSC, MRIC, chemist

Atomic Energy Research Establishment, Harwell J S HISLOP, BSC, PHD aluminium hydroxide or using water contaminated by aluminium for the preparation of dialysis fluid. ${ }^{12}$

We have noticed that the incidence of encephalopathy and spontaneous fractures in patients undergoing intermittent dialysis is unevenly distributed in the Trent Region. ${ }^{3-5} \mathrm{We}$ present here further information on the composition of the water supplied to the homes of our patients and the results of tissue analyses.

\section{Patients and methods}

All patients with end-stage renal failure treated by intermittent haemodialysis at home under the care of the Sheffield renal unit were considered ( 202 patients). They included patients who subsequently received a renal transplant.

Three groups were selected from this population.

Dialysis encephalopathy-Eleven patients developed a disease of the central nervous system for which no diagnosis other than dialysis encephalopathy was appropriate after full investigation. Seven had the typical syndrome of speech disturbance and myoclonic jerks slowly progressing to a mute paralytic state. Three patients, one of whom had fits for many months, developed rapid cerebral deterioration in association with generalised infection. One patient had suffered fits for many months with severe depression and weight loss, and he eventually died from inanition. In three patients the illness had begun a few weeks after the establishment of a well-functioning renal transplant. Seven of these patients also had multiple pathological fractures and nine died (see table I).

Fracture-Twenty-one patients sustained a fracture after starting haemodialysis and before transplantation but had no brain disease. Eleven of these patients had multiple fractures.

No complications-This group comprised 36 patients who had undergone dialysis for at least four years without developing fractures or encephalopathy.

\section{DIALYSIS TECHNIQUE}

After several months' training in hospital all patients performed dialysis in their homes for three periods of six or seven hours each week. They used a Kiil, hollow-fibre, or coil dialyser with a surface 
area of about $1 \mathrm{~m}^{2}$. The dialysate contained $1.6 \mathrm{mmol} / 1(6.4 \mathrm{mg} /$ $100 \mathrm{ml}$ ) of calcium. All patients took $1.2 \mathrm{~g}$ of calcium carbonate daily and supplements of folic acid and intravenous saccharated iron oxide. Only patients with persistently high plasma phosphate concentrations were prescribed aluminium hydroxide, which they did not usually take enthusiastically. Patients who had histologically proved osteomalacia or serum calcium concentrations below $2 \cdot 2 \mathrm{mmol} / 1(8.8 \mathrm{mg} / 100 \mathrm{ml})$ after they had been established on haemodialysis received vitamin $D$.

\section{CHEMICAL ANALYSES}

Water-Water supplied to the patients' homes was analysed by the relevant water authorities, all of whom provided data on calcium and fluorine concentrations. Some authorities did not measure aluminium or manganese regularly but assured us that the concentrations of these elements in their water were extremely low. In addition, the aluminium and manganese content of the water supplied to the homes of several patients who developed encephalopathy was measured by neutron activation.

Tissues-Concentrations of aluminium, manganese, and about 20 other elements were measured by optical emission spectrography in portions of brain (cases 8 and 10) and bone (cases 8 and 9) from patients with encephalopathy. The specimens of cerebral cortex and cerebellum contained about equal amounts of white and grey matter. Brain from another patient (case 3) and bone from two others (cases 6 and 10)

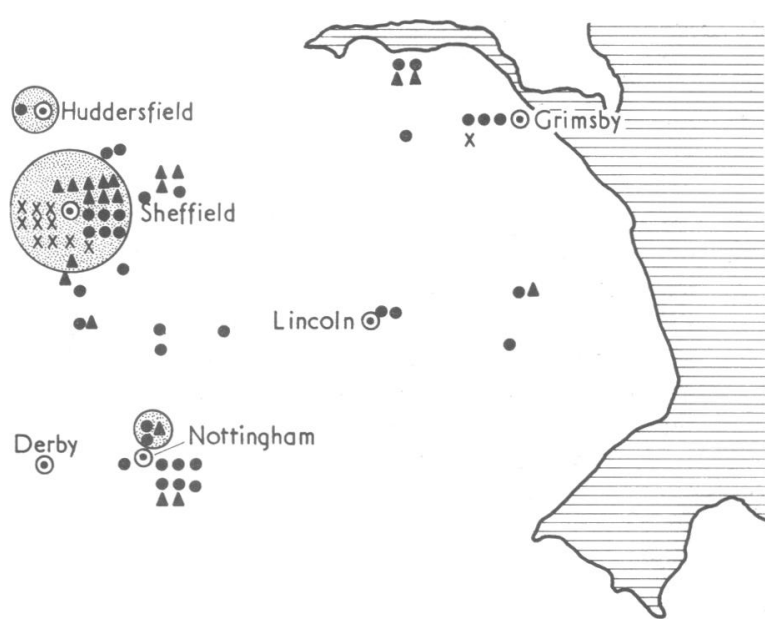

Map of Trent Region showing location of homes of patients Shaded areas indicate areas with "soft" water $(\leqslant 7.5 \mathrm{mmol} / \mathrm{l}$ $(30 \mathrm{mg} / 100 \mathrm{ml})$ of calcium $). \times=$ Patients with encephalopathy. $\boldsymbol{\Delta}=$ Patients with fracture(s) and no encephalopathy. $=$ Patients with no complications after $\geqslant 4$ years' dialysis. were analysed by neutron activation. Plasma phosphate was measured by autoanalyser, usually about 24 hours after dialysis. All available values for each patient (usually between 10 and 20) were averaged to give a single figure which was used in the statistical analysis.

The significance of differences between means was assessed by Student's $t$ test for unpaired data.

\section{Results}

Only two patients developed a fracture or encephalopathy within one year of starting dialysis. Fifteen of the 21 patients with fractures alone and all 11 patients with encephalopathy developed the first signs of these complications within four years of starting dialysis.

The map shows where each of the patients lived in the region. Ten of the 11 patients with encephalopathy $(91 \%)$, eight of the 11 patients with multiple fractures $(73 \%)$, but only two of the 10 patients with single fractures $(20 \%)$ and nine $(25 \%)$ patients without complications lived in the soft water areas. In three instances pairs of patients used the same house sequentially. Five patients with encephalopathy obtained their domestic water from the same combination of three reservoirs which served only one other patient on dialysis (table I).

Water supplied to patients with encephalopathy contained significantly $(P<0.05)$ more aluminium and manganese and less calcium and fluorine than that supplied to patients with no fractures or encephalopathy or patients with single fractures (table II). Eight of the 10 patients with DE whose water was analysed for aluminium received water that contained at least twice as much aluminium as that supplied to the patients without complications (tables I and II).

Of the patients with encephalopathy, six had taken aluminium hydroxide and only one patient had received neither aluminium hydroxide nor water with a high aluminium concentration (table I).

Three of the four specimens of bone from patients with encephalopathy (cases 6,8 , and 9) contained very large amounts of aluminium, but the aluminium content of brain from three patients with encephalopathy $(3,8$, and 10) was not increased. Brain from two demented patients contained $1 \mathrm{mg} / \mathrm{kg}$ dry weight of manganese, and ashed bone from the same patients contained less than $1 \mathrm{mg} / \mathrm{kg}$ of manganese. These values are similar to those in normal people. ${ }^{16}$; 8 Concentrations of the other elements in bone, as determined by optical spectrography, were not raised in cases 8 and 9 except for tin, which was present in a concentration of $20-25 \mathrm{mg} / \mathrm{kg}$ dry weight compared with under $3 \mathrm{mg} / \mathrm{kg}$ in controls. Similarly, within the sensitivity limitations of the emission spectrographic method, no evidence for "abnormal" concentrations of other elements was found in brain from cases 8 and 9. There was no significant difference in the mean plasma phosphorus concentration between any of the groups except when the lower posttransplant figures were included in the patients with encephalopathy (table II).

In view of these findings we compared two methods of removing aluminium and manganese from water. The results (table III) showed that a cation-exchange resin water softener did not remove aluminium or manganese consistently from water whereas a deioniser did. Dialysate prepared from a commercial solution of concentrated electrolytes and deionised water contained $0.03 \mathrm{mg} / 1$ of aluminium.

TABLE I-Data on aluminium concentrations in water and in tissues in patients with dialysis encephalopathy

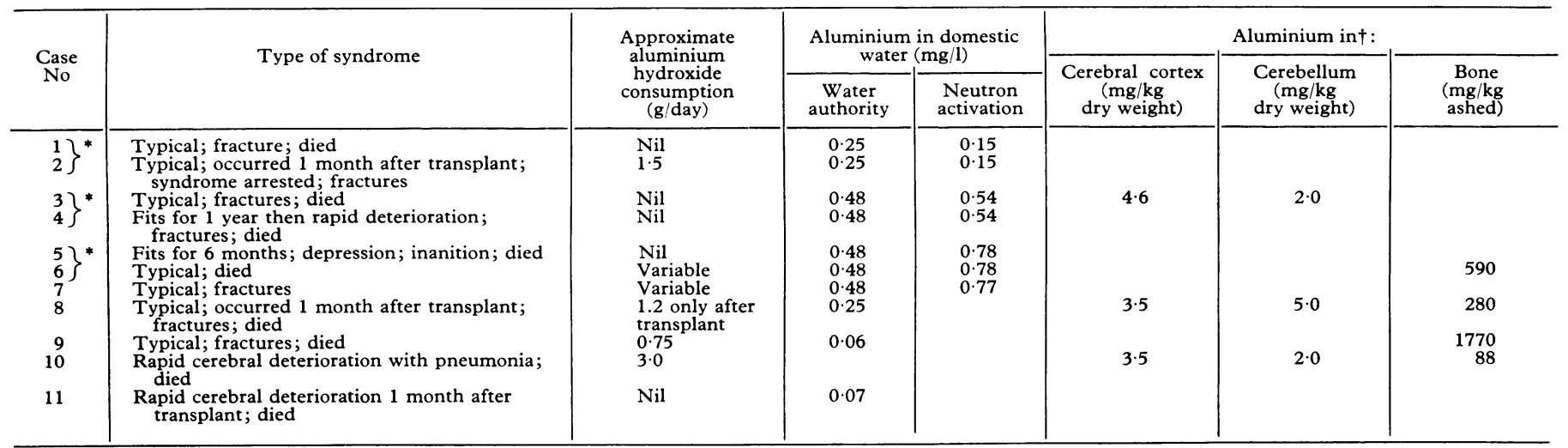

*Braces indicate that the two patients lived in the same house, though at different times.

Braces indicate that the two patients lived in the sane house, though at diferent times. tComparative mean concentrations of aluminium (and ranges) taken from published reports ${ }^{2} \mathrm{~g}-811-12$
$(1-18)$ in brain and $50 \mathrm{mg} / \mathrm{kg}(5-100)$ in ashed bone; for patients on dialysis without encephalopathy, $8 \mathrm{mg} / \mathrm{kg}(1-20)$ in brain and $50 \mathrm{mg} / \mathrm{kg}(8-420)$ in bone; for patients $(1-18)$ in brain and $50 \mathrm{mg} / \mathrm{kg}(5-100)$ in ashed bone; for patients on dialysis with
with encephalopathy, $16 \mathrm{mg} / \mathrm{kg}(4-96)$ in brain and $600 \mathrm{mg} / \mathrm{kg}(200-1778)$ in bone. 
TABLE II-Significance of differences in domestic water composition and plasma phosphorus concentration, according to incidence of fractures and dialysis encephalopathy

\begin{tabular}{|c|c|c|c|c|c|c|c|c|c|c|c|}
\hline & & \multicolumn{8}{|c|}{ Domestic water concentrations (mg/l) } & \multirow{2}{*}{\multicolumn{2}{|c|}{$\begin{array}{l}\text { Plasma phosphorus } \\
\text { (mmol/l) }\end{array}$}} \\
\hline & & \multicolumn{2}{|c|}{ Calcium } & \multicolumn{2}{|c|}{ Fluorine } & \multicolumn{2}{|c|}{ Aluminium } & \multicolumn{2}{|c|}{ Manganese } & & \\
\hline & & $\begin{array}{c}\text { No of } \\
\text { patients }\end{array}$ & Mean & $\begin{array}{l}\text { No of } \\
\text { patients }\end{array}$ & Mean & $\begin{array}{c}\text { No of } \\
\text { patients }\end{array}$ & Mean & $\begin{array}{c}\text { No of } \\
\text { patients }\end{array}$ & Mean & $\begin{array}{c}\text { No of } \\
\text { patients }\end{array}$ & Mean \\
\hline $\begin{array}{l}\text { No fractures or } \\
\text { encephalopathy after } \\
\quad 4 \text { years' dialysis } \\
\text { One fracture } \\
\text { Multiple fractures } \\
\text { Encephalopathy ... }\end{array}$ & $\begin{array}{l} \\
\cdots \\
\cdots \\
\cdots\end{array}$ & $\begin{array}{l}36 \\
10 \\
11 \\
11\end{array}$ & $\begin{array}{l}53 \cdot 0 \\
49 \cdot 8_{+}^{+} \\
35 \cdot 9^{+} \\
18 \cdot 4 \S\end{array}$ & $\begin{array}{l}36 \\
10 \\
11 \\
11\end{array}$ & $\begin{array}{l}0.37^{*} \\
0.500_{\ddagger}^{+} \\
0 \cdot 15^{\dagger} \\
0 \cdot 10 \S\end{array}$ & $\begin{array}{r}15 \\
7 \\
7 \\
10\end{array}$ & $\begin{array}{l}0.08 \\
0.024_{+}^{+} \\
0.16^{+} \\
0.328 \S\end{array}$ & $\begin{array}{r}18 \\
6 \\
8 \\
11\end{array}$ & $\begin{array}{l}0.027 \\
0.030 \ddagger \\
0.046 \\
0.082 \S\end{array}$ & $\begin{array}{l}36 \\
10 \\
10 \\
11\end{array}$ & $\begin{array}{c}1.67^{*} \\
1.75 \\
1.98 \\
1.80(1.56 \dagger)\end{array}$ \\
\hline
\end{tabular}

Domestic water concentrations were supplied by water authorities.

$\mathrm{P}<0.05$ for: ${ }^{*}$ No complications $v$ multiple fractures; $+\mathrm{DE} v$ multiple fractures; $\ddagger \mathrm{DE} v$ one fracture; $\S \mathrm{DE} v$ no complications.

First value is mean of pretransplant values only; value in parentheses includes also post-transplant values.
Conversion: SI to traditional values-Plasma phosphorus: $1 \mathrm{mmol} / 1 \approx 3.1 \mathrm{mg} / 100 \mathrm{ml}$.

TABLE III-Effect of treatment of tap water with resin cation ion exchange softener or deioniser. Concentrations were measured by neutron activation

\begin{tabular}{|c|c|c|c|c|c|c|}
\hline \multirow{2}{*}{$\begin{array}{c}\text { Sample } \\
\text { No }\end{array}$} & \multicolumn{3}{|c|}{ Aluminium (mg 1 ) } & \multicolumn{3}{|c|}{ Manganese $(\mathrm{mg} / \mathrm{l})$} \\
\hline & $\begin{array}{l}\text { Untreated } \\
\text { water }\end{array}$ & $\begin{array}{l}\text { Softened } \\
\text { water }\end{array}$ & $\begin{array}{l}\text { Deionised } \\
\text { water }\end{array}$ & $\begin{array}{l}\text { Untreated } \\
\text { water }\end{array}$ & $\begin{array}{l}\text { Softened } \\
\text { water }\end{array}$ & $\begin{array}{l}\text { Deionised } \\
\text { water }\end{array}$ \\
\hline $\begin{array}{l}1 \\
2 \\
3 \\
4 \\
5 \\
6 \\
7\end{array}$ & $\begin{array}{l}0.77 \\
0.78 \\
0.33 \\
0.09 \\
0.54 \\
0.15 \\
0.60\end{array}$ & $\begin{array}{l}0.60 \\
0.51 \\
\\
0.41 \\
0 \cdot 14\end{array}$ & $\begin{array}{l}0.09 \\
0.01\end{array}$ & $\begin{array}{l}0.23 \\
0 \cdot 11 \\
0.025 \\
0 \cdot 26 \\
0.04 \\
\\
0 \cdot 15\end{array}$ & $\begin{array}{l}0.25 \\
0.60 \\
0.018 \\
0.07 \\
0.02\end{array}$ & $0 \cdot 014$ \\
\hline
\end{tabular}

\section{Discussion}

Only five pairs of our 202 patients have ever used the same house for dialysis, yet three of these pairs developed encephalopathy. Therefore something in the environment probably caused the disease. The common water supply of five of the patients with encephalopathy (cases 3, 4, 5, 6, and 7) and the uneven geographical distribution of the cases suggested that some contaminant in the water supply may have been responsible.

The three reservoirs in the Sheffield district that supply water to the homes of these five patients (cases 3, 4, 5, 6, and 7) have the highest concentrations of aluminium and manganese. The aluminium in two of these reservoirs is added as aluminium sulphate to flocculate brown contaminants from soft moorland water, whereas the aluminium in the third reservoir and the manganese in all three is from natural sources. The water authority analyses were carried out on specimens from the water works while those examined by neutron activation were taken from the patient's homes at later dates. The degree of agreement between the two sets of results suggests that the measurements were accurate and that the aluminium and manganese were in the water source and not added by contamination from the patient's plumbing.

Alfrey ${ }^{1}$ was the first to find high concentrations of aluminium in grey matter of cerebral cortex from patients who had died from encephalopathy, but the amount of aluminium which he found in other parts of the brain was only minimally increased. We have not confirmed the presence of increased amounts of aluminium in brain from patients with encephalopathy, possibly because we did not separate white from grey matter. Other workers have found large amounts of aluminium in bone and other tissues of dialysis patients, but the difference between the concentrations in those with and without encephalopathy was not impressive.

Until Flendrig ${ }^{2}$ found high concentrations of aluminium in the water supplied to his patients with encephalopathy it had been assumed that the source of the aluminium found in such patients was the aluminium hydroxide taken as a phosphate binder by many patients on dialysis. This can be discounted as the sole cause of dialysis encephalopathy since five of our patients never took aluminium hydroxide. Many metals, such as manganese, lead, organic tin and mercury compounds, bismuth, and possibly aluminium, ${ }^{9}$ cause encephalopathy, and the same metals also accumulate in bone. The occurrence of encephalopathy after successful transplantation and cessation of dialysis may be due to release of stored trace metal from bone as a result of immobilisation, secondary hyperparathyroidism, and the administration of large doses of prednisolone. This hypothesis is supported by the progress in case 2 . This young woman underwent dialysis for two years and then developed encephalopathy about four weeks after receiving a renal transplant. She fractured several ribs spontaneously about the same time. Her encephalopathy began with fits but within four weeks she was mute and almost completely paralysed though conscious. She appeared moribund. Transplant function continued to be good and the dose of prednisolone was reduced. She then improved slowly for six months, but for the past year she has been in an unaltering state in which she is fully conscious, lucid, and speaking normally, though her mental faculties are mildly impaired. She has epilepsy controlled by drugs and has full use of her arms but cannot stand. Her electroencephalogram remains grossly abnormal and recent computerised tomography of the brain shows atrophy of the right cerebral hemisphere. We believe that she has now excreted her stored noxious trace element(s) but has permanent, residual, non-progressive brain damage. She is the only patient who has recovered to some degree from this disease.

The strong association between the occurrence of multiple fractures and encephalopathy 2510 and the similarity in their geographical distribution and in the composition of the water supplied to these patients suggests a common cause. Pierides et $a l^{10}$ suggested that the syndrome of encephalopathy and associated fractures may be due to phosphate depletion caused by aluminium hydroxide. But our results do not support this hypothesis.

We found that a cation-exchange softener did not reliably remove aluminium and manganese from water. In the case of aluminium this may be because this metal is present in water either in a colloidal form or as an anionic complex. It is probably present as an anionic complex since strongly complexing lignands-for example, fluoride or various organic compounds derived from humic acid-are present in Sheffield water under conditions that favour complex formation.

We conclude that some contaminant in the water used for dialysis is very probably responsible for the development of dialysis encephalopathy and pathological fractures. It is a remarkable coincidence that Alfrey ${ }^{1}$ found a high concentration of aluminium in grey matter of the brains of patients with encephalopathy, Flendrig ${ }^{2}$ discovered a disintegrating aluminium pump in the water supplying his patients with encephalopathy, and we found that the water supplying most of our patients with encephalopathy contained unusually high concentrations of aluminium. Nevertheless, our failure to detect high concentrations of aluminium in the brains of our patients with encephalopathy and the presence of increased concentrations of manganese in the same water makes it possible that some other contaminant in water is responsible for the syndrome. We regard the 
case against aluminium as not proved. But patients who dialyse in areas where the aluminium or manganese content of water is high should be supplied with deionisers. A water softener is inadequate.

We thank the water authorities of our region for supplying us with the results of their analyses, and $\mathrm{Mr}$ Bob Dixon for advice on the statistical analyses.

\section{References}

${ }^{1}$ Alfrey, A C, Le Gendre, G R, and Kaehny, W D, New England fournal of Medicine, 1976, 94, 184.
2 Flendrig, J A, Kruis, H, and Das, H A, Lancet, 1976, 1, 1235.

${ }^{3}$ Platts, M M, Moorhead, P J, and Grech, P, Lancet, 1973, 2, 159.

${ }^{4}$ Platts, M M, Grech, P, and McManners, T, British fournal of Radiology, 1973, 46, 585.

${ }^{5}$ Platts, M M, and Hislop, J S, Lancet, 1976, 2, 98

${ }^{6}$ Hamilton, E J, Minski, M J, and Cleary, J J, Science of the Total Environment, 1972, 1, 341 .

Aspangh, L R, et al, Report UCRL, 51013, part 2. Lawrence Livermore Radiation Laboratory, Berkeley, University of California, 1971.

8 Tipton, I H, and Cook, M J, Health Physics, 1963, 9, 103.

$\checkmark$ McLaughlin, A I G, et al, British fournal of Industrial Medicine, 1962, $19,253$.

10 Pierides, A M, Ward, M K, and Kerr, D N S, Lancet, 1976, 1, 1234.

11 Clarkson, E M, et al, Clinical Science, 1972, 43, 519.

12 Crapper, D R, Krishnan, S S, and Quittkat, S, Brain, 1976, 99, 67.

(Accepted 22 fuly 1977)

\title{
Fulminant Wilson's disease with haemolysis and renal failure: copper studies and assessment of dialysis regimens
}

\author{
ADRIAN N HAMLYN, JOHN L GOLLAN, ADRIAN P DOUGLAS, SHEILA SHERLOCK
}

British Medical fournal, 1977, 2, 660-663

\section{Summary}

Two girls, aged 12 and 17 years, presented with hepatocellular dysfunction and severe haemolysis due to Wilson's disease (hepatolenticular degeneration). This was accompanied by acute renal failure. In the absence of renal function sufficient for the urinary excretion of penicillamine, studies were performed to assess the potential of peritoneal dialysis, ascites removal by ultrafiltration-reinfusion, and haemodialysis as alternative excretory pathways for copper. The greatest amount of copper, as judged by rising bath concentrations, seemed to be eliminated with haemodialysis. But this was accompanied by a progressive increase in serum copper concentrations with rapid clinical and biochemical deterioration leading to death within 48 hours. A small amount of copper was lost with ascites removal. Significant amounts of copper were removed during peritoneal dialysis (36 $\mu \mathrm{mol} / \mathrm{day}(2287 \mu \mathrm{g} / \mathrm{day}))$, although a clinical response was not evident before haemodialysis was introduced. The administration of penicillamine orally, intravenously, or intraperitoneally produced no measurable increase in copper excretion into the peritoneal dialysate.

Hence peritoneal dialysis alone appears to offer the greatest potential benefit with regard to both eliminating copper and altering the course of this fulminant form of Wilson's disease.

Department of Medicine, Royal Victoria Infirmary, Newcastle upon Tyne NE1 4LP

ADRIAN N HAMLYN, BSC, MRCP, first assistant in medicine

Department of Medicine, Royal Free Hospital, London NW3

JOHN L GOLLAN, MD, FRACP, Wellcome research fellow (present address: Depar.nent of Medicine, University of California, San Francisco, California 94143)

ADRIAN P DOUGLAS, MD, MRCP, senior lecturer in medicine (present address: Department of Medicine, University of South California, School of Medicine, Los Angeles, California 90033)

SHEILA SHERLOCK, MD, FRCP, professor of medicine

\section{Introduction}

Wilson's disease (hepatolenticular degeneration) usually presents with clinical signs of chronic hepatic or neurological dysfunction. Haemolytic anaemia may precede these manifestations ${ }^{1}$ and is usually brief. Rarely, however, when haemolysis occurs together with hepatic decompensation, rapid deterioration ensues if the condition is not diagnosed early. ${ }^{2}$ We describe here two fatal cases of Wilson's disease. Both patients developed hepatic failure, severe haemolysis, and acute renal failure. Acute renal failure does not seem to have been reported before in association with Wilson's disease. Since the most effective chelating agent, penicillamine, is cleared from the plasma by the kidneys, peritoneal dialysis and haemodialysis were assessed in these patients as alternative means of eliminating the increased tissue copper stores. In addition, the role of penicillamine in the presence of renal insufficiency was evaluated in relation to peritoneal dialysis.

\section{Case 1}

This premenarchial 12-year-old girl experienced malaise with irritability and drowsiness 10 days before admission. Three days later profound anorexia developed with the passage of dark urine. She was feverish and had raised serum aspartate aminotransferase (SGOT) concentrations.

Over the next three days jaundice appeared, her level of consciousness deteriorated, and she was admitted to the Royal Victoria Infirmary.

Examination showed scratch marks, chest acne, and red striae on breasts, abdomen, and thighs. Ascites was present but not hepatosplenomegaly. Melaena stools were being passed and she was anuric. The diagnosis of Wilson's disease was suggested by the presence of Kayser-Fleischer rings.

Investigations confirmed haemolytic anaemia with haemoglobin concentration of $8.7 \mathrm{~g} / \mathrm{dl}$, reticulocyte count of $34 \%$, and reduced plasma haptoglobins. The Coombs test gave a negative result. The blood urea concentration was $13.2 \mathrm{mmol} / 1(79.5 \mathrm{mg} / 100 \mathrm{ml}$ ) (normal $<7.0 \mathrm{mmol} / \mathrm{l}(42 \mathrm{mg} / 100 \mathrm{ml})$ ). Prothrombin time was $36 \mathrm{~s}$ (control $13 \mathrm{~s})$. Serum total bilirubin concentration was $1080 \mu \mathrm{mol} / \mathrm{l}(63.2 \mathrm{mg} /$ $100 \mathrm{ml}$ ) (normal $<17 \mu \mathrm{mol} / 1 \quad(0.99 \mathrm{mg} / 100 \mathrm{ml})$ ), of which 800 